\title{
Economic Growth Model of Vietnam: Simultaneous Equation System
}

\author{
NGUYẼ̃N HOÀNG BẢO \\ University of Economics HCMC - hoangbao@ueh.edu.vn
}

\begin{tabular}{|c|c|}
\hline ARTICLE INFO & ABSTRACT \\
\hline 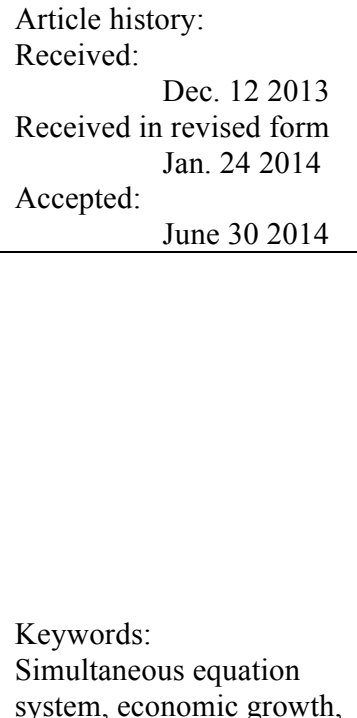 & $\begin{array}{l}\text { The paper discusses how internal and external factors affect } \\
\text { economic growth in the economic literature and explores the } \\
\text { economic mechanisms through which the macroeconomic variables } \\
\text { might impact economic growth directly and indirectly. The } \\
\text { simultaneous equation system is employed in order to introduce the } \\
\text { key macroeconomic behavior functions using the Vietnamese data } \\
\text { for the period } 1986-2013 \text {. The findings are: (1) the major } \\
\text { contribution to economic growth is the quantity of investment } \\
\text { instead of the quality of investment; (2) the optimal macroeconomic } \\
\text { stability has positively affected economic growth; (3) exports have } \\
\text { positively impacted on economic growth; (4) the public investment } \\
\text { crowds in the private investment generally; and (5) the income, } \\
\text { capacity utilization, and the optimal inflation have positively } \\
\text { impacted consumption. The paper also shows that the GDP growth } \\
\text { rate does not capture well the economic performance of the country } \\
\text { because it does not take into account the net factor payment from } \\
\text { abroad, natural resource depletion, and the inefficient intra-industry } \\
\text { trade. }\end{array}$ \\
\hline
\end{tabular}

intra-industry trade. 


\section{INTRODUCTION}

\section{a. Problem Statements:}

How important are the domestic and foreign resources to economic growth? Do the different types of government policy (fiscal, monetary, trade, and foreign capital control) have different impacts on economic growth? The paper aims to explain the contribution of economic growth and the economic mechanism through which some key macroeconomic variables impact economic growth directly and indirectly using the Vietnamese data for the period 1986 - 2012.

Vietnam's economy has experienced very strong economic growth (seven to eight percent annually) for almost three decades. However, there are the following problems: (i) this growth has slowed down in recent years due to the world recession; (ii) the quality of this growth has reduced sharply; (iii) this growth is mainly foreign resource-based (imports and foreign investments) rather than domestic-based path; and, (iv) the country has experienced a slow pace of economic reforms. The paper aims to identify the main factors contributing to economic growth and drawing policy implications for the near future.

\section{b. Data Sources:}

Most of the data employed in this study came from various sources: the International Monetary Fund, the Asian Development Bank, the World Bank and the International Financial Corporation Sources, and the Government Statistical Office in Vietnam. All the variables are measured in constant 1994 prices . The current account, capital account, change in international reserves, and errors and omissions are measured in current prices. The study uses many macroeconomic identities and behavioral functions to recalculate and re-estimate the variables which do not occur in the same data sets. There is clearly ground for disaggregation in order to obtain more meaningful results. The estimation period $1986-2012$ (27 observations) was determined by the availability of adequate data on all related variables.

\section{c. Research Questions:}

The research questions which are addressed in the paper are as follows: 
How does the foreign resource and domestic resource impact economic growth directly and indirectly?

How do the domestic factors attract the foreign direct investment directly and indirectly?

How do the domestic factors stimulate the private investment?

How do the domestic and foreign factors impact the export performance directly and indirectly?

\section{d. Outline of the Paper:}

The paper is academically structured as follows: section one is the introduction. Section two reviews literature on economic growth. Section three presents descriptive and comparative macroeconomic indicators and behavior of economic growth rates over the past twenty six years since 1986. Section four introduces the macro-econometric model and estimates the simultaneous equation system. Section five summarizes major findings, offers policy implications, and suggests venues for further research.

\section{LITERATURE ON ECONOMIC GROWTH}

There is a sizable economic literature that discusses how factors affect economic growth. In this section, the most important themes of the literature are summarized.

In the 1950s and 1960s, the most important post-Keynesian growth model was Harrod (1939) and Domar (1946) model. This model quantifies the delicate balance between income, savings, investment, and output required to maintain stable growth and full employment in a market economy. It was used by many development economists to identify savings and investment rates needed to achieve self-sustained growth in a market economy. The model has been used extensively in developing countries as a simple way of looking at the relationship between growth and capital requirement. The shortcomings of this model were as follows: (i) the outputs of any economic unit (enterprise, industry, or the whole economy) depend on the investment; (ii) the capital per worker is assumed to be constant; and (iii) the model does not take into account the increase of labor productivity, technological improvements, changes of skilled labor force, and the contributions of trade. 
The traditional two-gap model of Chenery \& Strout (1966), built upon the Harrod-Domar model, posited that the saving gap is the shortfall between available domestic savings and the level of investment needed to generate desired growth. The model also stated that the foreign-exchange gap is the shortfall between the level of imports associated with the available export earnings. The two-gap model has been extended to a third gap which is the fiscal gap. This gap is added because so many developing countries experience fiscal problems that undermine the growth prospects.

The view of the original two-gap and three-gap models, that foreign capital inflows can supplement domestic savings and raise the rate of growth as long as the absorptive capacity is large enough, was developed by Jansen (1990), who argued that such a higher rate of growth can be sustained only if foreign finance would flow forever, which is an unlikely assumption. To maintain the high growth rate but gradually reduce foreign dependence requires that either the average propensity to save increases or that the incremental capital output ratio falls (Jansen, 1990).

Although the model has been widely applied to more countries than other models, it has been criticized by a number of economists: (i) White (1992) argued that it is a very sticky model where there is no substitution in production either between factors to relieve capital shortage or reallocation of factors between sectors; (ii) the view of the original two-gap model, that all capital inflows would be used to finance investment, was criticized by Griffin (1970), who argued that part of the capital inflows would be consumed rather than invested so that domestic savings would decline and the increase in investment would be less than the increase in capital inflows; (iii) the capital inflows may negatively affect exports and foreign exchange balance. The capital inflows lead to an appreciation of the real exchange rate, which undermines export growth (Van Wijnbergen, 1986). The capital inflows to the public sector are invested in non-trade activities, while direct foreign investment may not only have a strong export orientation but may also be associated with a higher import intensive (Jansen, 1993); and (iv) debt-creating capital inflows will lead to claim on foreign exchange for debt servicing (Jansen, 1995). 
The Solow (1956) model is characterized by diminishing returns to capital in a closed economy, where technology is assumed to be exogenous. The policy implications of the Solow model are: (i) raising the saving rates will raise the growth rate of per capita income in the short-run period but not in the long-run period and will permanently raise its level; (ii) lowering the population growth rate will raise the growth rate of per capita income in the short-run period, but not in the long-run period and will permanently raise its level; (iii) policy reforms that raise the efficiency of the economy, such as trade liberation and financial development, will raise the growth rate of per capita income in the short-run period and permanently raise per capita income, but will not raise the steady-state rate of economic growth. A key prediction of the Solow model is worldwide income convergence. Countries with relatively low capital-labor ratios and low per capita income are predicted to grow faster than those with high capital-labor ratios and high per capita income. Based on statistical evidences, there have been two tendencies in the world: The developed countries exhibit strong convergence and the developing countries do not exhibit convergence in the past decades.

Human capital, because of its special role in innovative activities and technological progress, has formed the bedrock of the new theories of endogenous growth in recent years. Growth differentials between countries are not only explained by the differences in the efficiency of investment, but also explained by the differences in 'knowledge' and 'human capital' (Barro, 1991). In the 1980s, to overcome the limitations of the use of production function in explaining economic growth (appendix 2), the transformations of several exogenous variables to endogenous variables have been undertaken in the literature. The models of Romer (1990), Lucas (1988), and Becker et al (1990), which had the non-diminishing returns of human capital accumulation, implied that accumulation of the stock of human capital can impact the economic growth rate.

In addition to the development of the endogenous growth model, theoretical contributions that challenge the underlying assumptions of the neoclassical approach have revealed important directions for further inquiry. This is reflected in the proliferation of literature on imperfect information, the existence of transaction costs, incomplete market functions, and the roles of government and institutions. 
More recently, the focal point of growth literature has been the role of institutions and institutional changes in economic growth (Olson, 2000). The central argument is that the great differences in the wealth of nations are due mainly to differences in quality of their institutions and economic policies. The institutional concepts can be summarized into two definitions: the rule of game and the organization and structure of the governance of economic activities.

The first considers institutions as the rules of game, whereas the second sees institutions primarily as governing structures. The former emphasizes that, as a rule, institutions establish the baseline conditions for human interaction and give predictability to what other parties will do in particular contexts. They cover variety of topics from property rights (Svensson, 1998); to the role of the formal law (Cooter, 1996); and the impact of culture, norms and religion on human behavior and individual decision making (North, 1991). Countries with better institutions, more secure property rights, and less distortionary policies will invest more in physical and human capital and use these factors more efficiently to achieve a higher level of income.

The second definition of institutions focuses on the organization and structure of the governance of economic activities. Persson \& Tabellini (2003) have developed theoretical models linking economic performance with various political and institutional characteristics, including political accountability (Persson et al., 1997); electoral systems (Persson et al., 2003); size and scope of the government (Persson $\&$ Tabellini, 2004); and corruption (Persson \& Tabellini, 2003).

In the context of endogenous growth models, openness to international trade can affect economic performance through various channels, including learning by doing, specialization and spillovers (Lucas, 1988), transfer of knowledge and R\&D activities (Coe \& Helpman, 1995), and scale effect (Rivera-Batis \& Romer, 1991). However, depending on the models and the characteristics of the trading countries (level of development, human capital endowment, and so on), the overall impact of trade on growth can either be positive or unclear. Another aspect of international openness concerns financial flows, such as foreign investment, foreign aid, foreign debt, and portfolio investment. 
Foreign Direct Investment (FDI) induces knowledge and technology transfer and positively affects the host economy (Moran et al., 2005). In particular, FDI can generate positive externalities through demonstration effects, vertical linkages, and labor mobility, in addition to other sources that international investment brings to the host country. Furthermore, the impact of FDI needs to be considered in the context of the host economy's policy environment, such as trade regime and level of human capital (Keller, 1996).

There will be time lags between disbursement of aids and a recorded impact on growth. The time lag will depend on the type of aids (i.e., program or project), and if project aids, will probably depend upon the types of project selected (Kitchen, 1986). White (1992) correctly argued, "single equation estimation is inappropriate if any of the regressors form part of a simultaneous equation with either aid or the dependent variable. This is undoubtedly the case." Growth will be affected by the non-economic factors (e.g., demographic variables) that are likely to be interrelated or directly a function of aid inflows. He also concludes that three problems are identified with the literature reviewed: (i) the definition of the variables and the data quality; (ii) the understanding of the causes of the economic growth; and (iii) the models that capture the economic mechanisms through which aid might affect on growth.

Countries with better institutions, more secure property rights, more impact of culture, norms and religion on human behavior, and less distortionary policies will invest more in physical and human capital and use these factors more efficiently to achieve a higher economic growth. One of the surprising findings of Keynes (1936) is that there has been a chronic tendency throughout human history for the propensity to save to be stronger than the inducement to invest, and the desire of the individual to augment his personal wealth by abstaining from consumption has usually been stronger than the inducement to the entrepreneur to augment the national wealth by employing labor on the construction of durable assets. With these findings, Keynes concludes that the duty of ordering the current volume of investment cannot safely be left in private hands, and the government takes an ever greater responsibility for directly organizing investment. 
This section critically summarizes the theories of economic growth which are widely accepted as fact in the existing literature on economics. It builds up the macroeconomic framework for the following section.

\section{ECONOMIC GROWTH IN VIETNAM: COMPARATIVE AND DESCRIPTIVE DATA ANALYSIS}

As a preliminary step to the simultaneous equation estimations in the following section, section 3 presents a brief review of the Vietnamese economy and a summary of the data on the behavior of growth rates and the factors of resource for the different time periods. The historical development and growth of Vietnam can be broken down into two periods: before and after the renovation. The aim of this section is to see what kinds of different behavior patterns are presented by the different categories. It would be interesting to see whether there have been any significant changes in these variables over time.

\section{a. Economic Growth-Supply Analysis:}

Economic growth could be either constrained by the supply side or demand side. The output of the economy could be expressed as follows:

$$
\mathrm{Y}=\min \left\{\mathrm{Y}^{\mathrm{S}}, \mathrm{Y}^{\mathrm{D}}\right\}(3.1)
$$

where $\mathrm{Y}^{\mathrm{S}}$ is the aggregate supply and $\mathrm{Y}^{\mathrm{D}}$ is the aggregate demand respectively.

On the supply side, the increment of the investment contributes to the economic growth by expanding capital stock and leading to a higher output (in terms of quantity) as well as improving the efficiency of the economy (in terms of quality). The contribution to economic growth, on the supply side, might be formulated as follows:

$$
g_{t}=\frac{G D P_{t}-G D P_{t-1}}{G D P_{t-1}}=\frac{I_{t-1}}{G D P_{t-1}} \times \frac{G D P_{t}-G D P_{t-1}}{I_{t-1}}
$$

where $\frac{I_{t-1}}{G D P_{t-1}}$ is the investment ratio or the quantity of growth, and $\frac{G D P_{t}-G D P_{t-1}}{I_{t-1}}$ measures the efficiency of investment, which illustrates how many units of GDP are generated from one unit of investment. 
Figure 1: Economic Growth, Investment Rate and Efficiency of Investment in Vietnam, Period 1986 - 2012 (constant price in the year 1994)

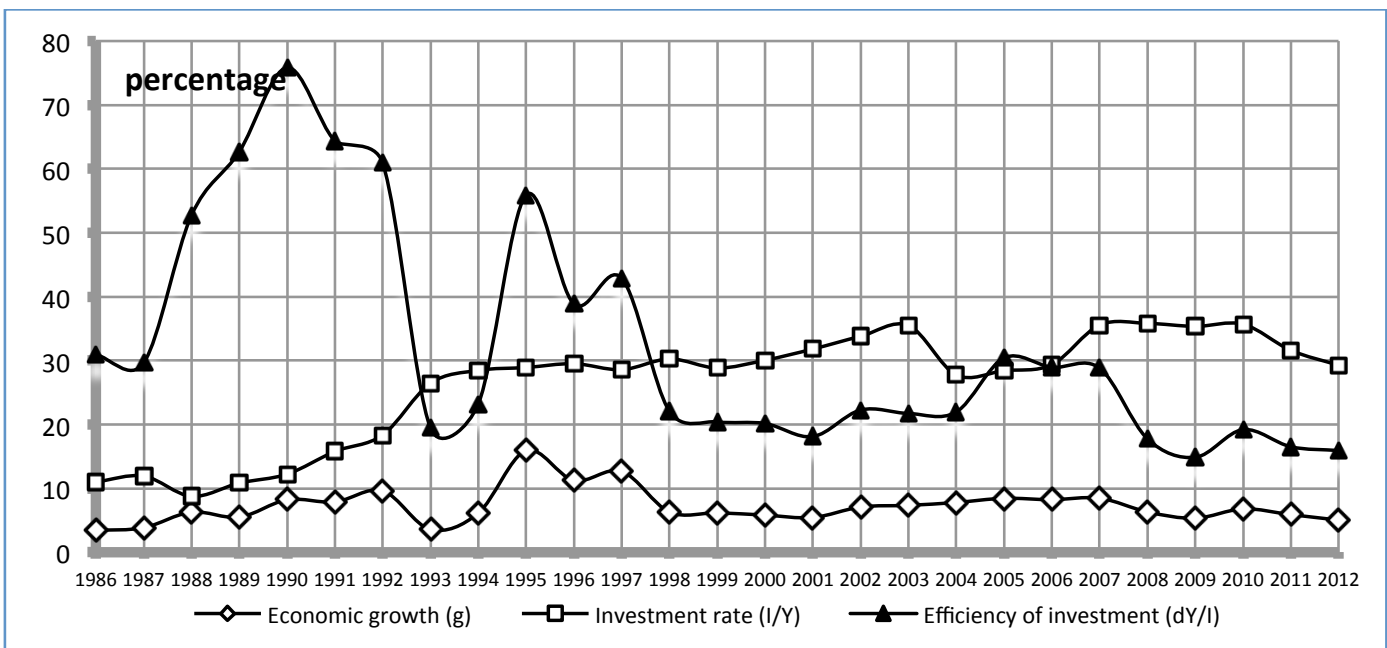

Sources: Calculated from the data of the Asian Development Bank (Various issues)

For nearly thirty years since renovation period, the performance of the economy, on the supply side, is as follows: (i) the major contribution to economic growth is the quantity of investment instead of the quality of investment (Figure 1). The investment rate increases over $30 \%$, which is comparatively high in the world and on the trend of saturation. The investment rate is declining in recent years; and (ii) the efficiency of investment drops dramatically, especially within six recent years since the global recession in the year 2007. Industrialization strategy requires the enhancement of the efficiency of investment in some priority industries rather than in all industries of the economy equally.

The Incremental Capital-Output Ratio (ICOR) possibly reflects the efficiency of the investment in an economy, especially in a long period. The ICOR tells us how much units of investment are required to produce one additional unit of GDP. The lower ICOR implies the higher level of efficiency, which implies an economy requires less investment to generate one unit increase in GDP. The higher ICOR, however, does not offer any conclusion immediately about the efficiency of the investment because some of them are being deployed or not operated properly in the short-run period. In the long - run period, higher ICOR definitely implies that an economy is an inefficient use of the investment. ICOR commonly varies 
between 2 to 3. Figure 2 describes the ICOR of Vietnam during the period 1986 2012. It has been very high, especially in the recent years. A word of caution to industries, provinces, and enterprises should check the feasibility of any investment project in the short-run and long-run periods. The problem of Vietnam is not only lacking of capital but also inefficient use of capital.

Figure 2: ICOR Index of Vietnam, Period 1986-2012

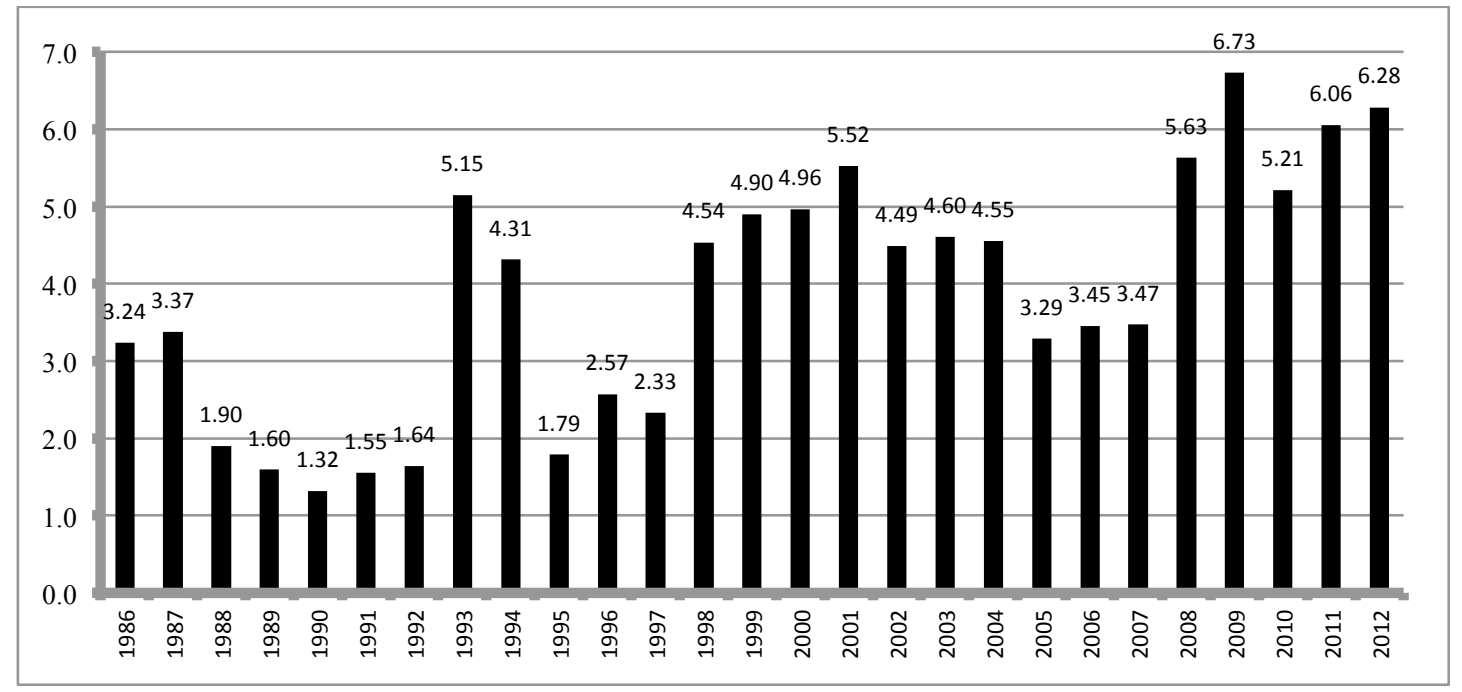

Sources: Calculated from the data of the Asian Development Bank (Various issues)

\section{b. Economic Growth-Demand Analysis:}

On the demand side, the identity of the aggregate demand of an economy can be written as follows:

$$
Y^{D}=C+I+E-M
$$

In which, $Y^{D}$ is the aggregate demand, $C$ is consumption, $I$ is investment, $E$ is export, and $M$ is import respectively. Government expenditure is decomposed into consumption and investment. The aggregate demand and its components in Vietnam have some trends: (a) when the aggregate demand increases, the consumption increases, but at a lower rate in comparison with the increase in aggregate demand. This is the Keynesian fundamental psychological law (Keynes, 1936). Figure 3 shows that the proportion of consumption in GDP declines over nearly three decades; (b) investment should be devoted to effective projects with high level of investment efficiency, or at least as the real interest rate, and the 
demand do not probably generate the supply, thus the enhancement of investment should be well-integrated into demand. Otherwise, there would be an increase in investment but decrease in consumption; and, (c) the relative increase of exports to imports would also significantly contribute to the effective demand.

Figure 3: Proportion of Aggregate Demand Components in GDP, Period 19862012

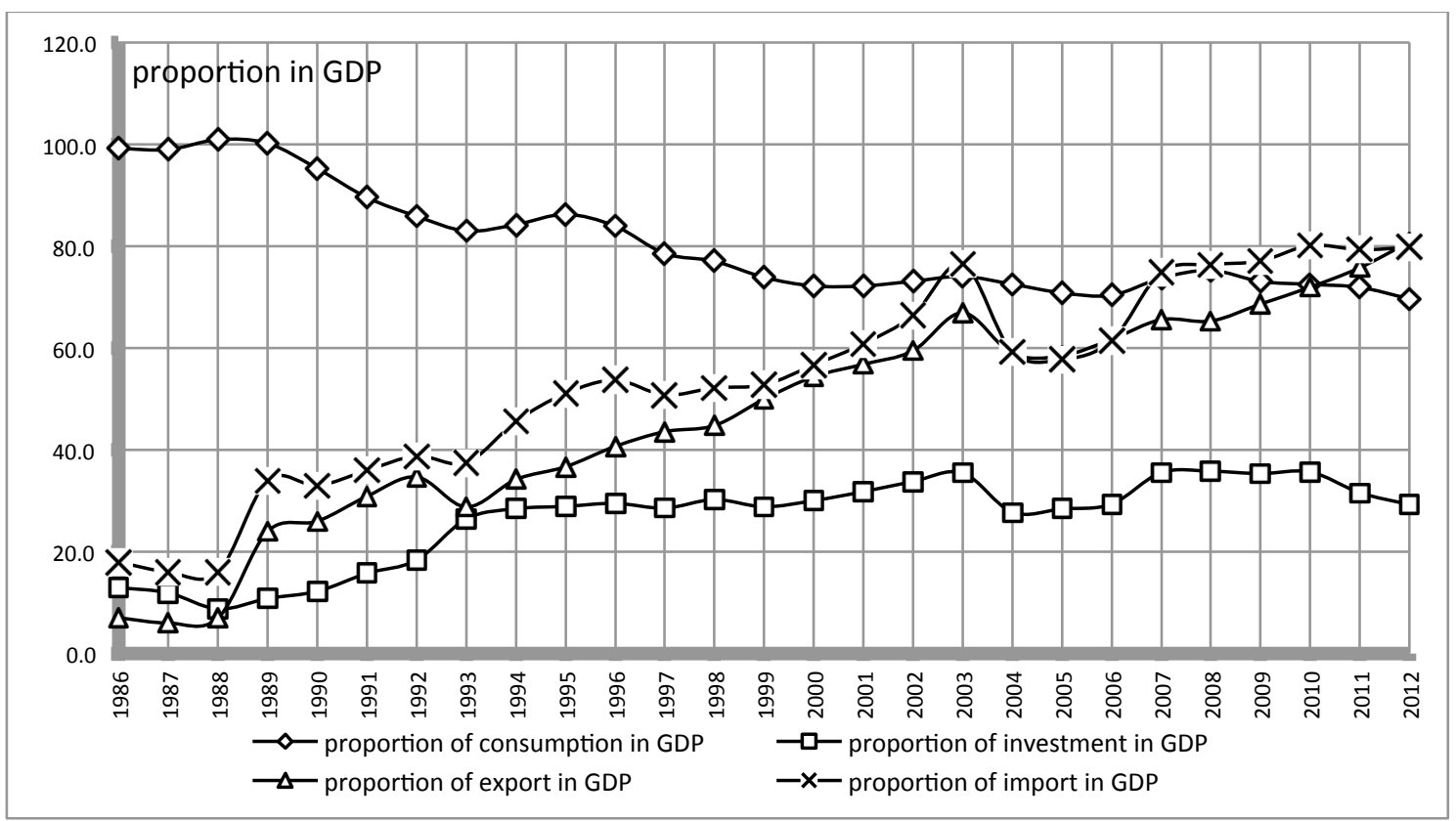

Sources: Calculated from the data of the Asia Development bank (Various issues)

Regarding the aggregate demand of an economy, the research focuses on the correlations among the growth rate of demand and the growth rates of its components. In order to do that, the matrix of correlation coefficients between the growth rate of the aggregate demand and the growth rate of its components is calculated. Table 1 shows that some pair-correlation coefficients are statistically significant different from zero, such as (i) the economic growth and the growth rate of consumption is significantly correlated; (ii) the growth rate of investment and the growth rate of export is significantly associated; and (iii) export growth rate is closely and statistically correlated to import growth rate. These findings are consistent with the analyses below. 
Table 1: Pair-Correlation among Economic Growth and the Growth Rates of Components of the Demand, Period 1986-2012

\begin{tabular}{lcccc}
\hline & $\begin{array}{c}\text { Economic } \\
\text { growth }\end{array}$ & $\begin{array}{c}\text { Growth rate of } \\
\text { consumption }\end{array}$ & $\begin{array}{c}\text { Growth rate } \\
\text { of investment }\end{array}$ & $\begin{array}{c}\text { Growth rate } \\
\text { of export }\end{array}$ \\
\hline Growth rate of consumption & 0.651 & & & \\
\hline Growth rate of investment & 0.115 & -0.039 & & \\
& $(0.575)$ & $(0.849)$ & & \\
Growth rate of export & 0.025 & 0.011 & 0.252 & 0.944 \\
\hline \multirow{2}{*}{ Growth rate of import } & $(0.902)$ & $(0.958)$ & $(0.215)$ & $(0.000)$ \\
\hline
\end{tabular}

Note: the numbers in the brackets are the p-values

Source: Calculated from the data of the Asia Development Bank (Various issues)

The structure of demand might reveal the position of an economy: the change of the domestic demand, the import-substitution effects, and the export-oriented effects along the line suggested by Chenery (1986) who uses the aggregate demand and its components to analyze the import-substitution effect or export-oriented effect.

This study starts with the aggregate demand identity (3.3), we transfer $M$ to the left hand side:

$$
\begin{aligned}
& Y+M=C+I+E \\
& \text { Let } D D=C+I
\end{aligned}
$$

DD denotes the domestic demand

Then $Y+M=D D+E$

where $\mathrm{Y}, \mathrm{M}, \mathrm{DD}$, and $\mathrm{E}$ are the GDP, imports, domestic demand, and exports respectively.

Denote $\mathrm{u}$ as the ratio of domestic production $(Y-E)$ and domestic demand $(D D)$ 


$$
u=\frac{Y-E}{D D}
$$

Then $Y=u D D+E$

The change of aggregate demand between two periods could be decomposed into three components:

$$
\delta Y=Y_{t}-Y_{t-1}=u(\delta D D)+\delta u(D D)+\delta E
$$

Where $u(\delta D D)$ is domestic demand effect, $\delta u(D D)$ is import-substitution effect, and $\delta E$ is export-oriented effect respectively.

Figure 4: Leontief Skylines of Domestic Demand, Import-Substitution Effect, and Export-Oriented Effects as Percentage of GDP

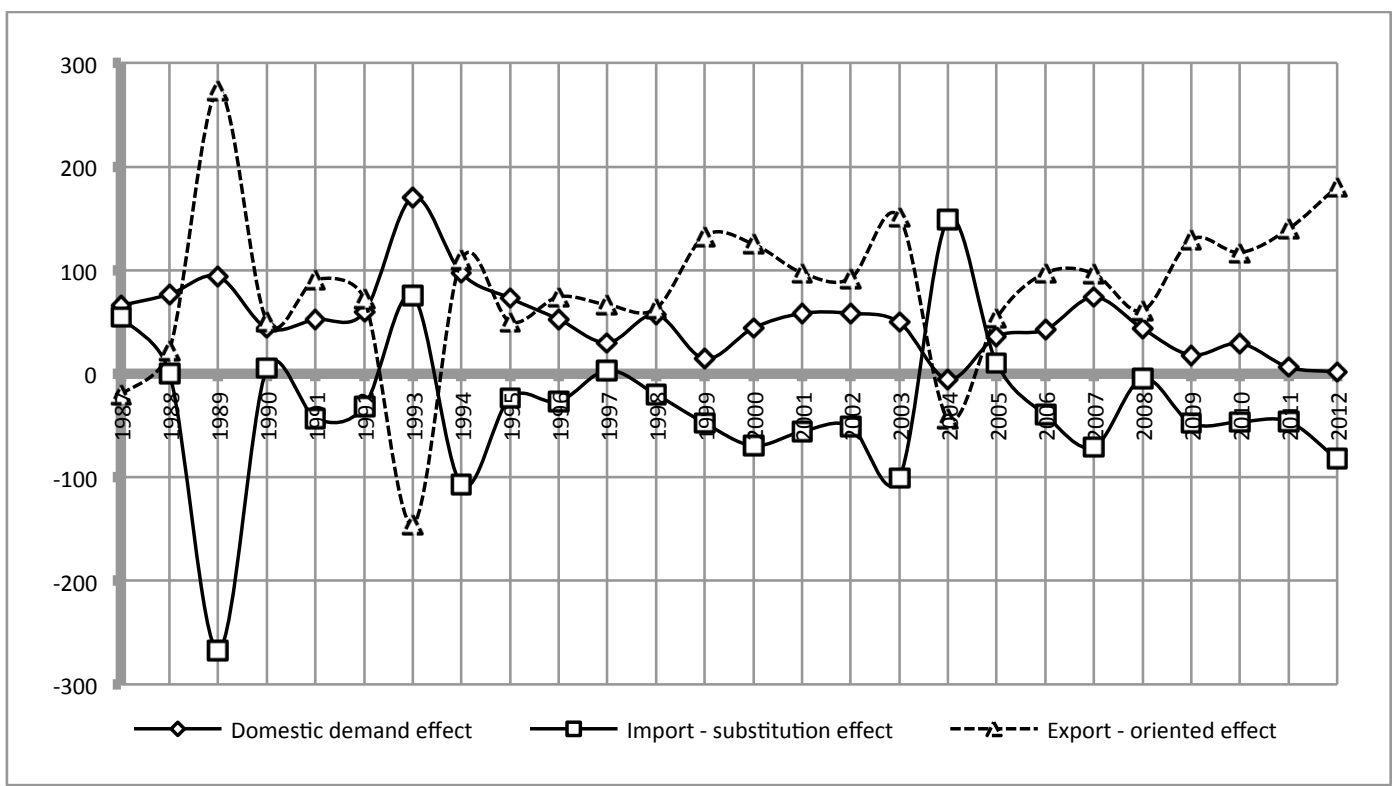

Sources: Calculated from the data of the Asia Development Bank (Various issues)

The Leontief Skylines show the proportion of GDP of demand components (Figure 4). The change of aggregate demand might be explained by (i) the domestic demand has sharply reduced since 2007 due to the world economic recession; (ii) the economy is much import dependency rather than import-substitution effect (import-substitution effect is negative over the period of concern, especially severely negative in recent years); and, (iii) the export-oriented effect is expanded in recent years. 


\section{c. Will Real GDP Growth Rate Well Capture The Economic Performance?}

Does the real GDP growth rate well capture the economic performance of the country in terms of efficient economic activity, or in terms of income generation, and in terms of national welfare? The real GDP growth rate does not take into account the net factor payment from abroad, natural resource depletion, and the inefficient intra-industry transactions.

The macroeconomic identity can ben written as follows:

$\mathrm{GNI}=\mathrm{GDP}+\mathrm{NFP}$

where GNI, GDP, and NFP are the gross national income, the gross domestic product, and the net factor payment/income, respectively. Since NFP is given as payments from abroad, if this is negative (or GNP is less than GDP) then the country is paying more to foreigners for the factor services than they are paying to the country (Figure 5, Panel a). Note that people might meet NFP defined as the net factor payments to abroad so that the sign in equation (3.1) is reversed. The question to address is the beneficiary of economic growth.

The real growth rate of the GDP ignores the contributions of the natural resources, especially the non-regenerative natural resources (crude oil and coal). There is a tradeoff between the current economic growth and future economic development. In principle, we might save this for the future generations. Figure 5 (Panel b) shows that the quantitative exploitation of crude oil has reduced in the recent nine years and coal have reduced in the recent six years.

The intra-industry trade has occurred when the country exports and imports the same products. The reasons for this are: (a) products are not homogenous. The country might export crude oil but import refined oil; (b) the difference between export price and import price might occur; and, (c) the import and export quotas might distort the market price. Grubel \& Lloyd (1975) use the Grubel-Lloyd (GL) index which measures the level of intra-industry trade.

$$
\mathrm{GL}_{\text {sectori }}=1-\left(\frac{\text { lexport }_{\text {sector }}-\text { import }_{\text {sectori }} \mid}{\text { export }_{\text {sectori }}+\text { import }_{\text {sectori }}}\right)
$$




\section{Figure 5: Real GDP Growth Rate Does Not Well Capture the Economic Performance}

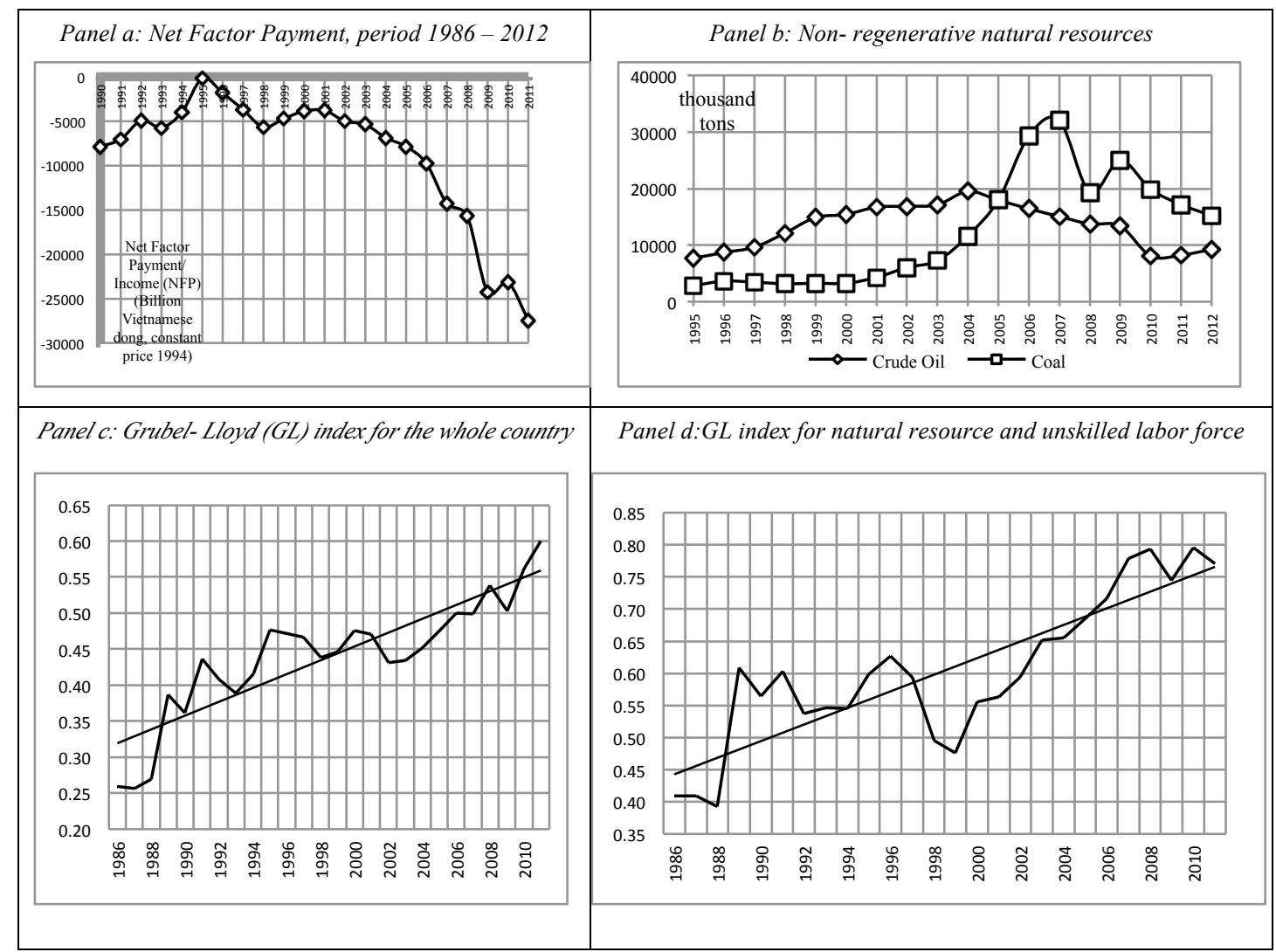

Sources: calculated from the data of the Asia Development Bank (Various issues); Vietnam Government Statistical Office

If GL is zero, there is no intra-industry trade. It is the most efficient case. The GL index for the whole country is increasing over three decades (Panel c, Figure 5). The industries of oil and tobacco and beverage have GL $=99 \%$. The country, with abundant natural resources and unskilled labor force, exports and imports the same products (Panel d, Figure 5).

\section{ECONOMIC GROWTH IN VIETNAM: SIMULTANEOUS EQUATION SYSTEM}

In the previous section, we examined the effects of macroeconomic variables on economic growth rate. However, all of these studies focus on the direct effects of the concerned variables. In this section, we take into account the direct and indirect 
effects. Sub-section one presents the sources of economic growth of Vietnam with the simultaneous equation system. Sub-section two estimates the model specification and explains the economic mechanism through which internal and external factors affect the growth rate.

\section{a. Sources of Economic Growth of Vietnam: Simultaneous Equation System:}

This sub-section investigates the internal and external determinants of economic growth. The dependent variable is, therefore, the output of the economy or the gross domestic products $(\mathrm{Y})$ which can be explained as follows:

$$
\log (\mathrm{Y})=\mathrm{a}_{0}+\mathrm{a}_{1} \log (\mathrm{I})+\mathrm{a}_{2} \log (\mathrm{E})+\mathrm{a}_{3} \log (\mathrm{FDI})+\mathrm{a}_{4}(\operatorname{Inf})+\mathrm{a}_{5}(\operatorname{Inf})^{2}+\mathrm{u}_{1}
$$

The investment (I), exports (E), and foreign direct investment (FDI) positively affect the GDP; the moderate inflation (Inf) also has a positive impact on the GDP. The moderate inflation rate brings sound business environment to economic activities; and the square inflation negatively impacts the GDP. The high inflation rate might worsen the business environment.

Most studies consider foreign direct investment (FDI) as an exogenous variable. It is practically impossible. The wise foreign investors might put their investment in the country with high economic activities or high economic growth (Y); the real exchange rate can positively impact foreign direct investment (Exchange); the moderate inflation rate might attract more investment (Inf); and, the squared of inflation might negatively impact foreign investment. The direct foreign investment function might be therefore written as follows:

$$
\log (\mathrm{FDI})=\mathrm{b}_{0}+\mathrm{b}_{1} \log (\mathrm{Y})+\mathrm{b}_{2} \log (\text { Exchange })+\mathrm{b}_{3} \operatorname{Inf}+\mathrm{b}_{4}(\mathrm{Inf})^{2}+\mathrm{u}_{2}
$$

The behavioral consumption function $(\mathrm{C})$ is given by:

$$
\log (\mathrm{C})=\mathrm{c}_{0}+\mathrm{c}_{1} \log (\mathrm{Y})+\mathrm{c}_{2} \log (\mathrm{u})+\mathrm{c}_{3}(\mathrm{inf})+\mathrm{c}_{4}(\text { inf })^{2}+\mathrm{u}_{3}
$$

where $u$ is the capacity utilization in the economy ( $\mathrm{u}=\mathrm{GDP} / \mathrm{GDPp}$ ) (GDPp is the potential real output of the economy). We expect that the coefficients $c_{1}, c_{2}$, and $c_{3}$ will positively impact consumption. The consumption is positively dependent on the income, the capacity utilization of the economy, and the moderate inflation; while the high inflation rate has a negative impact on consumption because it not only reduces the purchasing power, but also affects the structure of consumption.

The private consumption is represented by the behavioral function as follows: 


$$
\log (I p)=\mathrm{d}_{0}+\mathrm{d}_{1} \log \left(\operatorname{Ig}_{\mathrm{t}-1}\right)+\mathrm{d}_{2} \log (\text { Interest })+\mathrm{d}_{3}(\log (\text { Interest }))^{2}+\mathrm{u}_{4}
$$

where $I p$ and $\operatorname{Ig}_{\mathrm{t}-1}$ are the private investment and the public investment in the previous period of time ( $t-1)$ respectively; Interest is the real interest rate. We expect that the public investment crowds in the private investment (complementary effect). The real interest rate is the price of capital use or cost of holding money; $d_{2}$ is expected to have the positive sign; and $d_{3}$ is, expected to have the negative sign respectively.

The export is expressed by the following behavioral function:

$$
\log (E)=e_{0}+e_{1} \log (F D I)+e_{2} \log (M)+e_{3} \log (\text { Exchange })+u_{5}
$$

$\mathrm{e}_{1}$ is expected to have positive sign. When the foreign direct investment increases, exports will increase. It measures the export-oriented foreign direct investment in Vietnam. The foreign investors produce the products in Vietnam in order to take advantages of cheap unskilled labor force, abundant resources, and other advantages and export to the other countries; $\mathrm{e}_{2}$ is expected to have the positive sign. The result for this is that the Vietnamese exports, at the primary stage, have heavily relied on imported capital equipment, intermediate products and raw materials, which has made the economy more vulnerable to fluctuations in the world market; $\mathrm{e}_{3}$ is expected to have the positive sign.

The behavioral function of the money supply $\left(\mathrm{M}^{\mathrm{S}}\right)$ is expressed by:

$$
\log \left(\mathrm{M}^{\mathrm{S}}\right)=\mathrm{f}_{0}+\mathrm{f}_{1} \log (\text { GDP })+\mathrm{f}_{2} \log (\text { Interest })+\mathrm{f}_{3}(\log (\text { Interest }))^{2}+\mathrm{u}_{6}
$$

where $\mathrm{M}^{\mathrm{S}}$ is the money supply; GDP is the proxy measurement of the economic activity; and Interest is the yearly average real interest rate. This model does not use the real interest rate as the dependent variable. The result for this is that the nominal interest rate is controlled by the State Bank of Vietnam and only allowed to fluctuate within preset small bands.

\section{b. Economic Growth in Vietnam-Estimation in Simultaneous Equation System:}

In this sub-section, most of the variables are measured in the constant 1994 prices and in the period 1986 - 2012 (27 observations). Most of the data employed in this study will be obtained from various sources, such as the World Bank, the International Financial Statistics, the Asian Development Bank, and the 
Government Statistical Office. We check the four moments of each variables (moment one: mean, median, mode; moment two: standard deviation; moment three: skewness coefficient, and moment four: kurtosis coefficient) and transform the data into normal distribution. The simultaneous equation system is properly used to (1) overcome the problem of biased estimation in the single equation approach of any kind because the single equation approach greatly exaggerates and distorts the impact of exogenous variables on the endogenous variables concerned; and (2) explain the economic mechanism through which the independent variables might impact on endogenous variables directly and indirectly.

Before a simultaneous equations model is estimated, each equation is checked whether it is identified or not. The rank and order conditions are properly checked.

The rank condition is as follows: for an equation to be identified it must be possible to construct at least one $(M-1) x(M-1)$ matrix with a non-zero determinant from the coefficients of those variables excluded from that equation but included in other equations in the model (where $M$ is the number of endogenous variables in the system).

The order condition is used after rank condition is met. Order condition can be summarized as follows: If $(\mathrm{K}-\mathrm{k})<(\mathrm{m}-1)$, the equation is under-identified; if ( $\mathrm{K}$ $-\mathrm{k})=(\mathrm{m}-1)$, the equation is just identified; and, if $(\mathrm{K}-\mathrm{k})>(\mathrm{m}-1)$, the equation is over-identified. Where $\mathrm{K}$ is the number of exogenous variables in the model; $\mathrm{k}$ is the number of exogenous variables in the equation; and, $\mathrm{m}$ is the number of endogenous variables in the equation. The under-identified equations are not found in the model.

$$
\begin{aligned}
& \log (\mathrm{Y})=4.5784+0.0342 * \log (\mathrm{FDI})+0.2507 * \log (\mathrm{I})+0.4522 * \log (\mathrm{E})+0.0036 *(\operatorname{Inf})-3.73 \mathrm{E}-06 *(\operatorname{Inf})^{2}+\mathrm{u}_{1} \\
& (0.0000) \quad(0.0113) \quad(0.0000) \quad(0.0000) \quad(0.0000) \quad(0.0000) \\
& \log (\mathrm{FDI})=-24.5553+1.5155 * \log (\mathrm{Y})+1.3474 * \ln (\text { Exchange })+0.0073 *(\mathrm{Inf})-4.29 \mathrm{E}-06 *(\operatorname{Inf})^{2}+\mathrm{u}_{2} \\
& \begin{array}{llll}
(0.0000) \quad(0.0000) & (0.0000) & (0.0810)
\end{array} \\
& \log (C)=0.4707+0.9462 * \log (Y)+0.3135 * \log (\mathrm{u})+0.0006 *(\operatorname{Inf})-5.65 \mathrm{E}-07 *(\operatorname{Inf})^{2}+\mathrm{u}_{3} \\
& \begin{array}{llll}
(0.3402) \quad(0.0000) & (0.0082) \quad(0.0012) \quad(0.0221)
\end{array} \\
& \log (\operatorname{Ip})=-7.0976+0.9613 * \log \left(\operatorname{Ig}_{\mathrm{t}-1}\right)+5.3589 * \log (\text { Interest })-0.9029 *(\log (\text { Interest }))^{2}+\mathrm{u}_{4} \\
& \begin{array}{llll}
(0.0178) & (0.0000) \quad(0.0040) & (0.0080)
\end{array} \\
& \log (\mathrm{E})=-3.0958-0.0858 * \log (\mathrm{FDI})+1.1446 * \log (\mathrm{M})+0.1960 * \log (\text { Exchange })+\mathrm{u}_{5} \\
& \begin{array}{llll}
(0.0000) & (0.0001) & (0.0000) & (0.0000)
\end{array}
\end{aligned}
$$


$\log \left(\mathrm{M}^{\mathrm{S}}\right)=-18.1492+2.5526 * \log (\mathrm{Y})-1.6266 * \log ($ Interest $)+0.3446 *(\log (\text { Interest }))^{2}+\mathrm{u}_{6}$

$(0.0000) \quad(0.0000)$ (0.0293) $(0.0131)$

The p-values are in the brackets. The results of the simultaneous equation system are given in the Appendix 4. Only the square inflation rate variable in the foreign investment equation is not statistically significant and different from zero.

One important criterion for model evaluation is how well the model simulates the rapid changes in the data. The comparison of the actual and fitted data sets of the endogenous variables, such as the gross domestic products, foreign direct investment, consumption, private investment, exports, and money supply, is properly used. The simulated endogenous variables are close to their actual values. For the analytical purposes and hypothesis testing, the root-mean-square simulation error is used to measure the deviation of the simulated variable from its actual path time.

The outcomes of macro-econometric model and the policy implications are as follows:

- The economic growth is directly explained by the contributions of the foreign direct investment, the domestic investment, and the volume of exports. The moderate inflation rate might stimulate economic activity and thus economic growth. The high inflation rate reduces the economic activity (Equation 4.1).

- The attraction of the foreign investment is influenced by the economic activity, the real exchange rate, and the moderate inflation rate. This model attempts to make the foreign direct investment an endogenous variable. The wise foreign investors recognize that the country with high economic activities has high rate of return on investment. The foreign direct investment is further stimulated by the depreciation of the real exchange rate (Equation 4.2).

- On the demand side, the consumption is dependent on the income (Y); the capacity utilization $(\mathrm{u})$ which is measured by the ratio between real GDP and potential GDP; and, macroeconomic stability as a proxy measured by the moderate inflation rate (Equation 4.3).

- The high level of public investment in the previous period of time might actually attract more private investment (crowding-in). An increase in public investment may create conditions for profitable private investment (reduce cost), 
provide the demand impulse and hence have a positive impact on the level of private investment. The cost of capital will, of course, impact on private investment. The moderate real interest rate may stimulate private investment to some extent (Equation 4.4).

- The volume of exports is closely linked to the foreign direct investment. There has been the tendency of export-oriented foreign direct investment in Vietnam. The growth of capacity to export has been more dependent on the growth rate of imports. The depreciation of the real exchange rate might stimulate exports (Equation 4.5).

- The money supply $\left(\mathrm{M}^{\mathrm{S}}\right)$ is dependent on the economic activity (GDP) and the real interest rate (Equation 4.6).

\section{CONCLUSIONS}

The main purpose of this paper is to explore the direct and indirect effects of factors on economic growth in Vietnam. This section briefly summarizes the methodological approach, major findings, and policy implications, as well as suggestions on some directions for further research.

The methodological approaches in this paper are: (i) the model of the simultaneous equation system on the economic growth and the factors which explain the growth rate directly and indirectly and explain the direct causality; (ii) the comparative and descriptive data analysis is properly used to support the model specification and picking up some primary findings; and (iii) the intra-industry trade, alone the line suggested by Grubel-Lloyd (1975), is analyzed.

The paper overviews the economic growth theories and discusses its weaknesses. The economic growth rate in Vietnam, after the renovation period, is descriptively and comparatively analyzed. The findings are as follows: (i) the major contribution to economic growth is the quantity of investment, rather than the quality of investment; (ii) when the aggregate demand increases, the consumption increases, but at a lower rate in comparison with the increase in aggregate demand. The Keynesian fundamental psychological law can be observed in the economy for nearly three decades (Keynes, 1936); (iii) the increase of exports is highly associated with the increase of imports; and, (iv) the economy reflects import 
dependency instead of import-substitution effect along the line suggested by Chenery (1986).

The GDP growth rate does not well capture the economic performance of the country because it does not take into account the net factor payment from abroad, natural resource depletion, and the inefficient intra-industry trade. This is also a word of caution for policymakers who rely on the GDP growth as national achievement or performance.

Based on the theories of economic growth, the paper introduces a simultaneous equation system of the macroeconomic model for Vietnam in the period 1986 2013. The paper aims to check the economic mechanism through which some macroeconomic variables might impact economic growth directly and indirectly. The tests of stationarity of each variables, cointegration analysis, error correction model, and short-run and long-run impacts on the relevant variables are the shortcomings of the model specification

\section{References}

Asian Development Bank (2013), "The Key Indicators for Asia and the Pacific 2013" available at $<$ http://www.adb.org/publications/key-indicators-asia-and-pacific-2013, retrieved on Dec. 24, 2013>.

Bacha, E. L. (1990), "A Three-Gap Model of Foreign Transfer and the GDP Growth Rate in Developing Countries”, Journal of Development Economics, 32(2): 279-296.

Barro, R. J. (1991), "Economic Growth in a Cross Section of Countries", Quartely Journal of Economics, 106: 407-443.

Becker, G.S. et al. (1990), "Human Capital, Fertility, and Economic Growth", Journal of Political Economics, 98(5): 12-37.

Chenery, H. B. \& W. Strout (1966), "Foreign Assistance and Economic Development", American Economic Review, 66: 679-733.

Coe, D. \& E. Helpman (1995), “International R\&D Spillovers”, European Economic Review, 39: 859-87.

Cooter, R. (1996), The Rule of State Law versus the Rule-of-Law State: Economic Analysis of the Legal Foundations Of Development, World Bank, Washington, D.C.

Domar, E. (1946), "Capital Expansion, Rate of Growth and Employment”, Economitrica, 14: 13747. 
Government Statistical Office (2011), Exports of Goods by Standard International Trade Classification

Government Statistical Office (2011), Imports of Goods by Standard International Trade Classification

Government Statistical Office (2011), Vietnamese Household Living Standard Survey 2008.

Government Statistical Office (2013), Vietnamese Household Living Standard Survey 2010.

Griffin, K. (1970), "Foreign Capital, Domestic Savings, and Economic Development", Bulletin of the Oxford University Institute of Economics and Statistics, 32(2): 99-112.

Grubel, H.G. \& P. Lloyd (1975), Intra-Industry Trade: The Theory and Measurement of International Trade in Differentiated Products, Wiley, New York

Harrod, R.F. (1939), “An Essay in Dynamic Theory”, Economic Journal, 49 (March): 14-33.

Jansen, K. (1990), Finance, Growth, and Stability: Financing Economic Development in Thailand, 1960 - 86, Gower Publishing House, Aldershot.

Jansen, K. (1993), "Direct Foreign Investment and Adjustment, The Case of Thailand", Working Paper Series on Money, Finance and Development, The Hague: Institute of Social Studies.

Jansen, K. (1995), 'The Macroeconomic Effect of Direct Foreign Investment: The Case of Thailand”, World Development, 23(2): 193-210.

Keller, W. (1996), "Absorptive Capacity: On the Creation and Acquisition of Technology in Development", Journal of Development Economics, 49: 199-227.

Keynes, J. M. (1936), The General Theory of Employment, Interest, and Money, Macmillan Cambridge Press, published by Harcourt, New York.

Kitchen, R. L. (1986), Finance for Developing Countries, University of Bradford.

Krisna, K. et al. (2003), “Trade, Investment, and Growth: Nexus, Analysis and Prognosis”, Journal of Development Economics, 70: 479-499, North-Holland.

Lucas, R.E. Jr. (1988), “On the Mechanics of Economic Development', Journal of Monetary Economica, 22: 3-42.

Marrewijk, Charles Van (2008), Intra-Industry Trade, World Economy, Princeton University Press, Department of Economics, Erasmus University Rotterdam, Holland.

Morgan, T. H., E. M. Graham \& M. Blomstrom (eds) (2005), Does Foreign Direct Investment Promote Development?, Institute for International Economic Center for Global Development, Washington, D. C.

North, D.C. (1991), “Institutions”, Journal of Economic Perspectives, 5 (Winter): 97 - 112.

Olson, M. (2000), Power and Prosperity: Outgrowing of Capitalism and Dictatorship, Basic Books, New York. 
Persson, T., G. Roland \& G.E. Tabellini (1997), "Separation of Powers and Political Accountability", Quarterly Journal of Economics, 112: 310-27.

Persson, T., G. Roland \& G.E. Tabellini (2003), How Do Electoral Rules Shape Party Structures, Government Coalitions, and Economic Policies? Working Paper Series No. 10176: 1-60, National Bureau of Economic Research.

Persson, T. \& G.E. Tabellini (2003), The Economic Effects of Constitutions, MIT Press, Cambridge, Massachusetts.

Persson, T., G. Roland \& G.E. Tabellini (2004), “Constitutions and Economic Policy”, Journal of Economic Perspectives, 18 (1): 75-98.

Razmi, A. (2005), "Balance-of-Payment-Constrained Growth Model: The Case of India”, Journal of Post-Keynesian Economics, 27(4): 655-687.

Rivera-Batis, L. \& P. M. Romer (1991), "Economic Integration And Endogenous Growth", Quarterly Journal of Economics, 56: 531-55.

Romer, P. (1990), "Endogenous Technological Change”, Journal of Political Economy, 98: 71-102.

Svensson, J. (1998), “Investment, Property Rights, and Political Instability: Theory and Evidence”, European Economic Review, 42(7): 1317-41.

Solow, R. (1956), “A Contribution to the Theory of Economic Growth", Quarterly Journal of Economics, 70: 65-94.

Van Wijnbergen, S. (1986), "Macroeconomic Aspects of the Effectiveness of Foreign Aid: The Two- Gap Model, Home Goods Disequilibrium and Real Exchange Rate Mislignment”, Journal of International Economics, 21:123-136.

White, H. (1992), “The Macroeconomic Impact of Development Aid: A Critical Survey”, Journal of Development Studies, 28: 163-240. 